Body slender, more strongly narrowed cephalad and caudad than in media, the attenuation caudad being especially pronounced and gradual. The processes of the last carinæ shorter and much broader than in media; the processes of the two preceding segments differ in having the mesal margin much less oblique and more nearly symmetrical with the outer one, caudally rounded. The caudal extension of the posterior ends of the carinæ begins farther forward than in media.

Vertigial sulcus very deep, ending below on a level with the centers of the antennal sockets, not truly bifurcate through there is a vague fine line from its lower end to each antennal socket.

Sternites without processes.

Principal processes of gonopods gradually narrowing distad much as in media, but the glabrous distal region shorter and curving more abruptly and more decidedly mesad, the distal, subvertical edge not obtusely excised as in media. The minor dorsal (anterior) processes more slender than in media and not subparallel, extending each obliquely mesodistad.

Length of type (male) near $35 \mathrm{~mm}$.; width, $5.5 \mathrm{~mm}$.

Locality: North Carolina: Cranberry (Coll. Aug. 6, 1896. Rec'd for study through Prof. R. Thaxter.)

The type is abundantly infested with an Empusa. It is in the collection of the Department of Cryptogamic Botany at Harvard University.

\title{
A NOTE ON LIMATUS DURHAMI THEOBALD.
}

By C. S. Lublow.

An interesting omission in the available descriptions of this species, so far as the English and American authorities at least are concerned, was brought to my attention by the receipt of specimens sent by Colonel W. H. Wilson, M. C., United States Army, from the Canal Zone.

Neither in Mr. Theobald's description ${ }^{1}$ nor in that given by Howard, Dyar and $\mathrm{Knab}^{2}$ is mention made of a very noticeable and

\footnotetext{
1 Theobald, F. V., Monograph, Culic. II, p. 349. 1901. Ibid., III, p. 333. 1903.

${ }^{2}$ Howard, Dyar and Knab, Monograph, The Mosquitos of North and Central America and the West Indies, III, p. 40. 1912.
} 
beautiful marking on the male proboscis, and because of this omission I was led to hope that a new species had been sent me. However, comparison with the males at the National Museum showed the same marking on the specimens there, and then I found in the description of Simondella curvirostris Laveran ${ }^{1}$ quoted in the monograph of H. D. \& K. the following:

"Près de son origine elle est sombre à la face supérieure et présente, à la face inférieure un petit disque ovale garni d' écailles d'un bleu très vif."

As a matter of fact this little oval group of scales is very brilliant and suggests a sapphire set in the dark proboscis.

As this marking seems to have escaped entirely the notice of both the authorities mentioned it is perhaps worth while to call attention to it.

Army Medical Museum,

Washington, D. C.,

August 14, 1918.

NOTES ON CLOSTEROCERUS CINCTIPENNIS ASHM.," IN NEW JERSEY (HYMENOPTERA)

\author{
By Harry B. Weiss and Alan S. Nicolay \\ New Brunswick, N. J.
}

This species not heretofore recorded from New Jersey has been found by us at the following localities: New Brunswick, Jamesburg, Highbridge, Trenton, Bridgeton and Plainfield, and undoubtedly occurs in many other places in the state. It was described by Ashmead in his paper "Descriptions of Some New North American Chalcididæ" which appeared in Vol. XX, p. 104-1888 of the "Canadian Entomologist" and the habitat given is United States. It is also listed in "The Hymenoptera or Wasp-like Insects of Connecticut" as probably occurring in that state. Neither of the above publications mentions the hosts.

In New Jersey we have found C. cinctipennis to be parasitic upon the eggs and larvæ of Brachys ovata, the eggs of Brachys aerosa and

1 Laveran, C. R., heb. Soc. Biol., liv. 1160. 1902.

2 Identified by A. B. Gahan. 

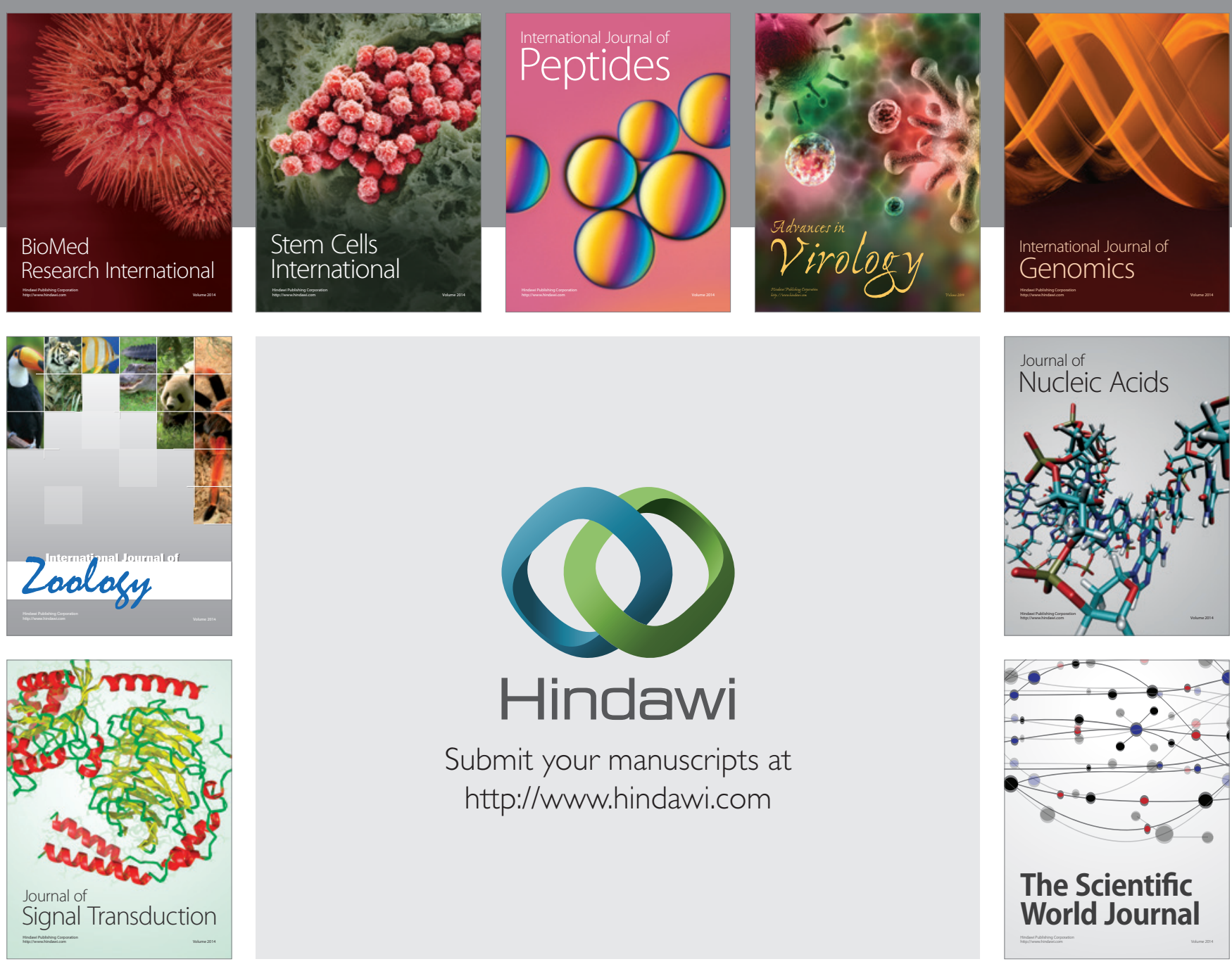

Submit your manuscripts at

http://www.hindawi.com
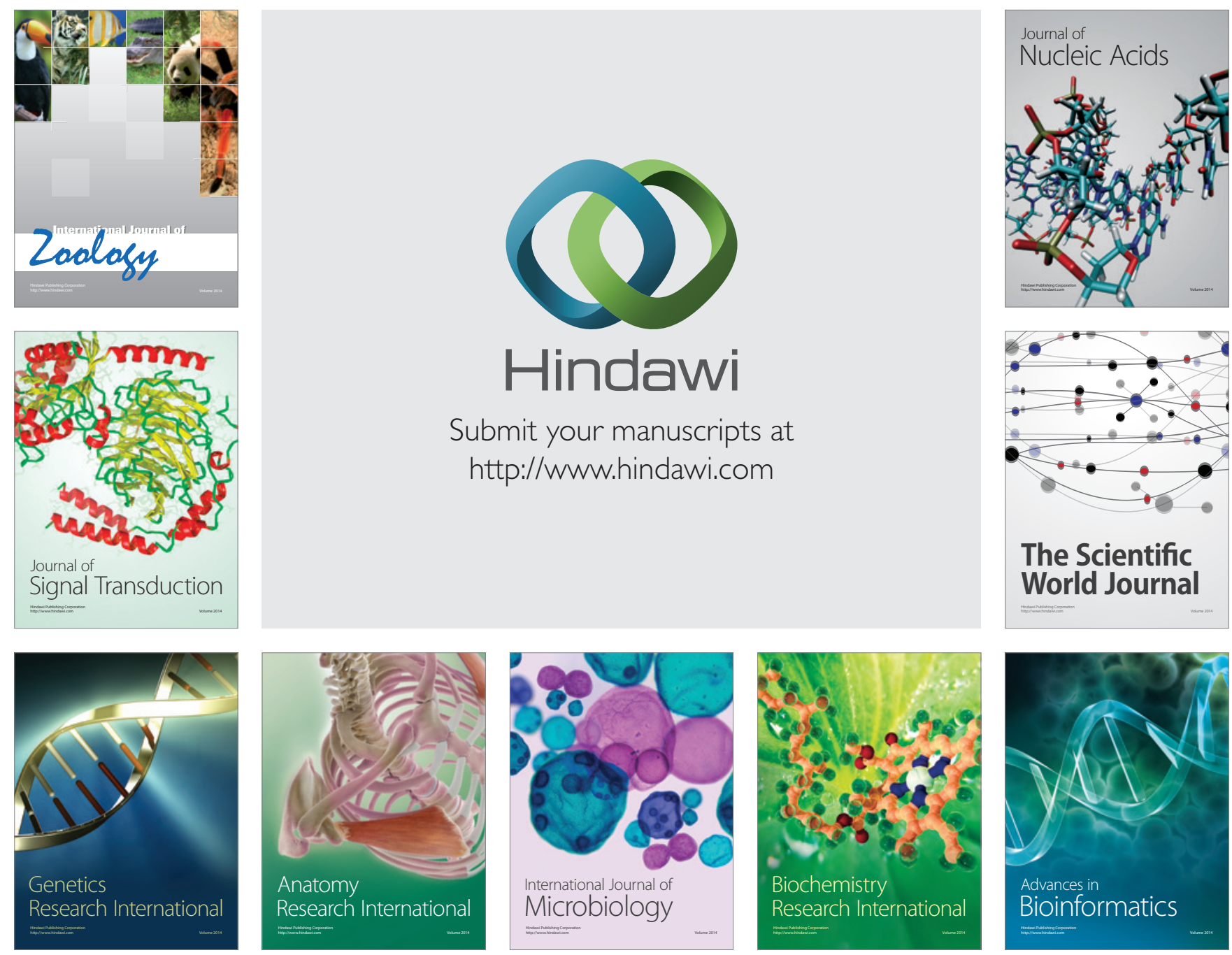

The Scientific World Journal
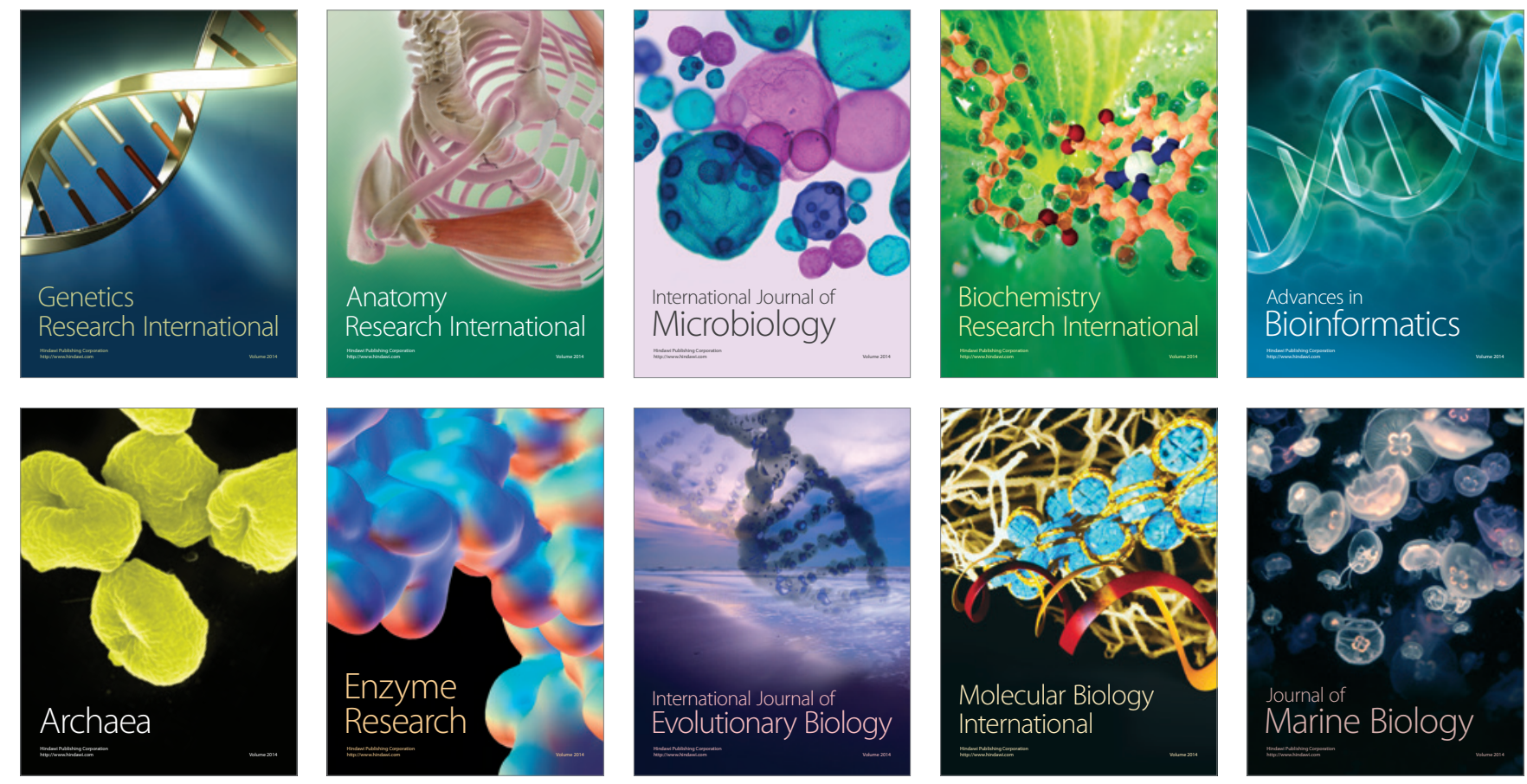